University of Nebraska - Lincoln

DigitalCommons@University of Nebraska - Lincoln

10-1-1999

\title{
Estimation of Demand for Wheat by Classes for the United States and the European Union
}

\author{
Samarendu Mohanty \\ lowa State University \\ E. Wesley F. Peterson \\ University of Nebraska-Lincoln, epeterson1@unl.edu
}

Follow this and additional works at: https://digitalcommons.unl.edu/ageconfacpub

Part of the Agricultural and Resource Economics Commons

Mohanty, Samarendu and Peterson, E. Wesley F., "Estimation of Demand for Wheat by Classes for the United States and the European Union" (1999). Faculty Publications: Agricultural Economics. 68.

https://digitalcommons.unl.edu/ageconfacpub/68

This Article is brought to you for free and open access by the Agricultural Economics Department at DigitalCommons@University of Nebraska - Lincoln. It has been accepted for inclusion in Faculty Publications: Agricultural Economics by an authorized administrator of DigitalCommons@University of Nebraska - Lincoln. 


\title{
Estimation of Demand for Wheat by Classes for the United States and the European Union
}

\author{
Samarendu Mohanty and E. Wesley F. Peterson
}

\begin{abstract}
This study estimates demand for wheat differentiated by classes using a dynamic AIDS model for the United States and the European Union (EU). The results suggest that imported wheat is more price responsive than domestic wheat in the U.S. market but not in the EU market. This may suggest that the Canadian policy that reduces prices of Canadian wheat in the U.S. market or U.S. export subsidies that raise prices of U.S. wheat could be expected to give rise to substantial substitution of Canadian for U.S. wheat. It is also found that in the EU, complementary relationships exist between spring and other wheat groups. This complementary relationship between the lower and higher quality wheat in the EU is not surprising because EU millers blend cheaper wheat such as EU common wheat and U.S. other wheat with high protein (spring) to obtain the preferred characteristics.
\end{abstract}

The world wheat market is one of the most widely studied commodity markets (McCalla; Alaouze, Watson, and Sturgess; Wilson, Koo, and Carter; and many others). Despite this interest, it remains one of the most controversial commodity markets because of its imperfectly competitive structure (large grain trading companies and state importers), product heterogeneity and the extensive government interventions in both exporting and importing countries. Among various aspects of the market, estimation of demand including export and import demand has received significant attention in past decades.

Most past studies estimating demand for wheat have either ignored or have failed to fully recognize two important factors, product differentiation of wheat and the dynamics in wheat demand functions. With respect to product differentiation of wheat, past studies can be divided into three different groups. First, many studies such as Konandreas, Bushnell and Green; and Gallagher et al. have assumed perfect substitutability across classes and origins. The second group of studies have allowed for imperfect substitutability either in terms of origin or end uses (Wang; Chai; Chang; and Agriculture Canada). Recently, Wilson (1994)

Mohanty is an associate scientist at the Center for Agricultural and Rural Development at Iowa State University. Peterson is a professor with the Department of Agricultural Economics at the University of NebraskaLincoln.

Journal paper No. J-18053 of the Iowa Agriculture and Home Economics Experiment Station, Ames, Iowa. Project No. 3109, and supported by Hatch Act and State of Iowa funds. estimated demand for wheat by allowing differentiation both by country of origin and end uses.

The importance of product differentiation of wheat where trade is the focus has been recognized by Alston, Gray and Sumner. Both Larue, and Wilson (1989) argue that wheat should be differentiated both by country of origin and end use. Larue found that the assumption of one form of differentiation or the other would be appropriate if countries specialize in one product type and the given product type is exported by only one country. In the case of wheat, this is not applicable because most countries trade more than one class of wheat. Sumner et al. point out that a single country would not both import and export a commodity that is homogeneous except, perhaps, for some limited border trade. The existence of widespread intraindustry trade in wheat is evidence that this product is differentiated in terms of origin, end use or both.

The importance of product differentiation of wheat is evident from recent interest among policy makers regarding bilateral trade flows of specific classes of wheat. For example, the increased volume of Canadian durum wheat exports to the United States in the early 1990s caused concerns among U.S. authorities, who argued that imports from Canada undermined U.S. price support programs. The U.S. government's case for material interference was primarily based on the fact that deficiency payments were determined by the domestic market price of wheat and imports from Canada increased the supply in the domestic mar- 
ket and consequently reduced the market prices, increasing deficiency payments (Sumner et al.) The extent of the impact of Canadian wheat on the U.S. domestic market, particularly prices, was analyzed by USDA (1994) and Alston Gray and Sumner using simulation models.

The USDA simulated the effects of reducing $\mathrm{Ca}$ nadian exports to the United States of all types of wheat to half of base run values in 1993-94. According to Alston et al., USDA stated that it modeled a restriction of wheat grain imports to $261 \mathrm{kt}$ (9.6 million bushels) without imposing any similar restriction on imports of flour and other wheat products, but assuming they would be unaffected by a wheat import quota. Taking into account the flour and wheat products, the USDA simulation actually restricted total imports to $22.4 \%$ of the base rather than $50 \%$. Later, Alston estimated the effects of Canadian imports by restricting Canadian imports of each type of wheat to $22.4 \%$ of the base to make their results comparable with those of USDA. USDA reported an increase in average U.S. prices of 9 cents per bushel and a deficiency payment cost about $\$ 230$ million lower, whereas Alston, Gray and Sumner found the U.S. price to increase by only 0.008 cents per bushel with deficiency payments $\$ 16$ million lower. Such differences in results could be attributable to varying assumptions regarding product differentiation of wheat and demand and supply elasticities. USDA appears to have aggregated all wheat types together, regardless of end uses and obtained quite small elasticities of demand and supply, whereas Alston, Gray and Sumner assumed product differentiation of wheat both by origin and end uses, employing much larger demand elasticities estimated from a synthetic approach. Clearly, accurate measures of demand function parameters are critical for policy analysis.

In addition to product differentiation of wheat, the different specifications used in previous studies to represent wheat demand are static in nature. Static demand specifications are unlikely to capture the behavior of consuming regions because it takes time to adjust fully to any changes in market conditions, including price changes. Several factors account for this slow adjustment on the part of consuming regions. Habit formation can generate delayed responses (Pollak and Wales). This is particularly true for wheat because an importer's preference for a specific class of wheat depends on its end uses. This is supported by Wilson, Koo and Carter, who found that importers are not indifferent between wheat of different origins. They also concluded that there was limited or no switching between wheat classes that are close substitutes in the case of several importers. This tends to freeze demand patterns in the short run because consumption of final goods and technological capabilities evolve fairly slowly so that there will be a tendency for limited responsiveness to short-run price variations. However, in a longer time frame, changes in final consumer demand and technological innovation could lead to shifts in importer preferences as millers discover ways to blend or enhance cheaper wheats to obtain the desired characteristics at lower cost. Millers in the EU have been able to concentrate protein and other desirable attributes in their relatively low-quality wheat, reducing the need to import North American wheat for blending (Leuck).

Another important reason for a slow response to price changes might be long-term trade agreements (LTA) between an importer and an exporter. LTAs typically involve shipment periods of two or more seasons and often provide an upper and lower bound on purchases (Harwood and Bailey). Thus, LTAs can decrease an importer's flexibility to respond immediately to market conditions. LTAs are widely used in world wheat trade (Harwood and Bailey). In the 1980 s, approximately 25 to $30 \%$ of world wheat was traded through LTAs (OECD).

The objective of this study is to estimate U.S. and European Union (EU) demand functions for wheat taking into account both product differentiation and functional forms. In both the EU and the United States, multiple classes of domestic and imported wheat are consumed. For example, U.S. wheat millers purchase different classes of domestic wheat as well as two major types (western red spring and durum) imported from Canada. Similarly, in the EU, domestically produced soft wheat (generally referred as common wheat) is consumed along with various classes of wheat imported from Canada and the United States. Clearly, the potential for substitution of imports for domestic production as well as between certain classes of wheat (e.g. hard red winter and hard spring wheats) may be of great importance for domestic market conditions and the realization of wheat policy objectives. Thus, for example, a high degree of substitutability between U.S. and Canadian durum wheat means that small price differentials could trigger substantial shifts in consumption patterns. On the other hand, if U.S. and Canadian durum wheats are imperfect substitutes, millers will find it more profitable not to disrupt their purchasing procedures in the face of small price differences. In these circumstances, accurate estimates of the own- and crossprice demand elasticities for various classes of wheat from different origins are essential for effective and accurate policy analysis. 
It is our contention that more accurate estimates will be obtained by including both wheat end uses and origin as sources of substitutability. For this study, wheat is differentiated into three categories according to end uses as well as according to national origin. The three primary industrial uses of wheat are for pasta made from durum wheat; bread from hard spring wheats and to a lesser extent hard red winters; and other milling products such as pastries and crackers made from hard red winter, soft and white wheats. Within each category, wheat from one national origin is differentiated from similar wheat from some other country or region. Thus, Canadian hard red spring wheat is treated as an imperfect substitute not only for hard red winter or other classes of wheat but also for hard red spring from the United States. Although Canadian durum and hard red spring are very similar to their U.S. counterparts, survey evidence indicates that many importers prefer the Canadian product for a variety reasons, not the least of which is a perception of the higher quality of the Canadian products (Pick et al.). In the case of durum wheat, the relevant issue is substitutability according to national origin because there is little scope for substitution between durum and other classes of wheat (Alston, Gray, and Sumner).

\section{Demand Specifications}

A traditional approach to identifying price responses in international trade is to employ the elasticity of substitution model. In this approach, logarithms of relative import ratios are regressed on logarithms of income and relative prices. The functional form used in the specification has been criticized because it is not derivable from an underlying model of optimization behavior. Another specification, the Armington model, also has been widely used in modeling trade flows of differentiated commodities. The Armington approach distinguishes imports by country of origin and uses a two-step procedure for the import decision. The model has been criticized because of its restrictive assumption that the elasticity of substitution is constant and equal across pairs of commodities (Alston, et. al.). According to Grennes, Johnson, and Thursby a naive constant share model has yielded superior predictions relative to the Armington model for heterogeneous commodities like wheat.

The Almost Ideal Demand System (AIDS) developed by Deaton and Muellbauer, an alternative specification derived from demand theory, has also been widely used in demand analysis. The model has been used to analyze import behavior with re- spect to aggregated wheat by Hennings and Martin. This study assumed product differentiation among classes but aggregated wheat of similar classes with different origins (i.e., U.S. durum was aggregated with Canadian durum, U.S. hard red spring with Canadian western red spring wheat).

More recently, Wilson (1994) used translog demand functions derived from dual relationships to estimate demand for wheat classes by Pacific Rim countries. The translog demand function used by Wilson is similar to the AIDS specification, except for the inclusion of a second-order logarithmic term for the expenditure variable. Using this approach, Wilson concluded that it may be inappropriate to allow differentiation by origin but found perfect substitutability across classes exported from a particular country.

As discussed earlier, a model that includes dynamic responses over more than one time period seems appropriate to represent the behavior of firms and consumers in the United States and the EU. This study uses a general dynamic demand framework extended to the AIDS system, following the procedure of Wickens and Breusch. The AIDS model seems to be the most robust choice of the many flexible demand systems available for specification in a dynamic setting (Anderson and Blundell 1983) because it is linear in nature and does not assume homogeneity or symmetry although neatly allows the testing of these as well as the homotheticity and homothetic separability. A similar dynamic specification has been used by Kesavan et al. to evaluate the dynamics and longrun structure of U.S. meat demand.

The AIDS model is derived by specifying a cost function representing a PIGLOG ${ }^{1}$ class of preferences. These preferences, represented by either cost or expenditure function, define the minimum expenditure necessary to attain a specific utility level at a given price. The cost function $c(u, p)$ for utility $u$ and price vector $p$ can be defined using the PIGLOG class of preferences by

$$
\log c(u, p)=(1-u) \log a(p)+u \log b(p),
$$

where $u$ lies between 0 and 1 so that the positive linear homogeneous functions $a(p)$ and $b(p)$ may be regarded as the costs of subsistence and bliss. The functional forms for $a(p)$ and $b(p)$ are chosen such that the first and second derivatives of the cost function can be set equal to those of an arbitrary cost function, thus satisfying the necessary condition for flexibility of functional form.

\footnotetext{
${ }^{1}$ PIGLOG is a special form of the price-independent, generalized (PIGL) class of preferences.
} 
The demand function is derived from the cost function using Shepherd's lemma because of the fundamental property of the cost function that its price derivatives are the quantity demanded. Multiplying both sides of the first derivatives of the cost function by $p_{i} / c(u, p)$, the left-hand side may be expressed as a budget share and the right-hand side may be expressed as a function of prices and utility. The cost function is then solved for $u$ and the resulting term is substituted for $u$ in the budget share equation. Thus, we have budget shares as a function of $P$ and $M$ (total expenditures) and a single equation of budget share can be represented as:

(1) $W_{i t}=\alpha_{i}+\sum_{j=1}^{n} \gamma_{i j} \ln \left(P_{j t}\right)+\beta_{i} \ln \left(M_{t} / P_{t}\right)+u_{t}$,

where $W_{i t}$ is the $i^{\text {th }}$ budget share, $P_{j}$ is the price of $j^{\text {th }}$ commodity, and $M$ is the total budget outlay. The original price index is nonlinear and is usually replaced by Stone's price index $(P)$. Stone's price index is based on the weighted average of prices by budget share and is defined as

$$
\log (P)=\sum_{i=1}^{n} w_{i} \log \left(p_{i}\right) .
$$

Use of Stone's price index allows for a linear estimation of the system. When the Stone price index is used in equation 1 , the system is referred to as the linear approximation of the Almost Ideal Demand System (LA/AIDS) (Blanciforti et al.). Homogenity, Slutsky symmetry and adding up can be imposed on the system by imposing the following restrictions:

Homogeneity:

$$
\sum_{j} \gamma_{i j}=0
$$

Adding up:

$$
\sum_{j} \alpha_{i}=1 ; \sum_{i} \gamma_{i j}=0 ; \sum_{j} \beta_{i}=0 .
$$

Symmetry:

$$
\gamma_{i j}=\gamma_{j i}
$$

If homogeneity, symmetry and adding up are not rejected, then the estimated demand functions are homogeneous of degree zero in prices and expenditure taken together, satisfy Slutsky symmetry and add up to the total expenditure (Deaton and Muellbauer). Both Marshallian and Hicksian measures of elasticities can be computed from the estimated parameters of the linear approximation of the AIDS model as follows:

$$
\begin{aligned}
& \eta_{i i}=-1+\gamma_{i i} / \mathrm{w}_{i}-\beta_{i} \\
& \eta_{i j}=-1+\gamma_{i j} / \mathrm{w}_{i}-\beta_{i}\left(\mathrm{w}_{j} / \mathrm{w}_{i}\right) \\
& \delta_{i i}=-1+\gamma_{i i} / \mathrm{w}_{i}-\mathrm{w}_{i} \\
& \delta_{i j}=-1+\gamma_{i j} / \mathrm{w}_{i}-\mathrm{w}_{j}
\end{aligned}
$$

where $\eta$ and $\delta$ denote Marshallian and incomecompensated or Hicksian elasticities respectively. Expenditure elasticities can be estimated using the following formula.

$$
e_{i}=1+\beta_{i} / w_{i}
$$

where $e_{i}$ denotes expenditure elasticities of ith wheat type.

Following equation 1, the general dynamic specification of the AIDS model in a distributed lag form is given by

$$
W_{t}=\sum_{k=1}^{p} \lambda_{k} W_{t-k}+\sum_{k=0}^{p} \delta_{k} X_{t-k}+u_{t},
$$

where $X$ is a vector of prices and expenditures used in the AIDS model. $k$ is the order of the lag structure for the exogenous and dependent variables, $k$ $=1, \ldots p . \delta_{0}$ is the vector of parameters in the AIDS model (equation 1). By repeated substitution for lags of $W$, the steady state relation between the endogenous variable and exogenenous variables $(X)$ may be expressed as

$$
W_{t}=\frac{\sum_{k=0} \delta_{k}}{1-\sum \lambda_{k}} X_{t}=\Theta X_{t} .
$$

where $\Theta$ is the long-run multiplier defined as the sum of the coefficients of current and lagged values of the exogenous variables divided by one minus the sum of the lag coefficients of the dependent variables.

The normal procedure is to estimate equation 3 and then calculate the long-run multiplier using the above formula. Thus additional computations are required to obtain both the estimates of $\Theta$ and its standard error. Since $\Theta$ is a nonlinear function of unconstrained coefficients ( $\delta$ and $\lambda$ ), the determination of its standard error is quite cumbersome (Kmenta, 1986, pp. 485-95). A more convenient approach would be to re-write the model in such a way that a point estimate of $\Theta$ and its standard error could be obtained directly without the need for further calculations.

As pointed out by Hendry et al., past studies have used nine different dynamic specifications that have been derived from equation 3 by imposing coefficients restrictions, so that long-run mul- 
tipliers can be estimated directly. Some frequently used dynamic specifications include the partial adjustment, the error correction model and the general dynamic specification.

As indicated earlier, this study uses a general dynamic specification following the procedure of Wickens and Breusch. This is obtained by subtracting $\sum_{k=1}^{P} \lambda_{k} W_{t}$ from both sides of the autoregressive form of the AIDS model (equation 3 ) which leads after algebraic manipulation, to:

$$
\begin{aligned}
W_{t}= & -d \sum_{k=1}^{p} \lambda_{k} \Delta_{k} W_{t}+d\left(\sum_{k=0}^{p} \delta_{k}\right) X_{t} \\
& -d \sum_{k=1}^{p} \delta_{k} \Delta_{k} X_{t}+d u_{t},
\end{aligned}
$$

where $d=1 /\left(1-\sum_{k=1}^{P} \lambda_{k}\right)$ and $\Delta$ is the difference operator. This provides point estimates of the previously defined long-run multiplier and its standard error. The general dynamic AIDS model nests partial adjustment, autoregressive, and static versions of the AIDS model. Since it is expressed in a dynamic form without any restrictions, it is referred to as the general dynamics AIDS (GD/ AIDS). Thus, this model provides an opportunity to test for alternative model specifications. The generalized partial adjustment model (GP/AIDS) can be obtained by imposing $\lambda_{k}=0$ for $k \neq 1$ and $\delta_{\mathrm{k}}=0$ for $k=1,2, \ldots p$. Similarly, the static model(S/AIDS) can be obtained by imposing $\lambda_{k}=$ $0 \forall k$ and $\delta_{k}=0 \forall k$. These restrictions provide the opportunity to test the nested models within the GD/AIDS

\section{Data and Estimation}

Two separate demand systems, one for durum and the other for spring and other wheat classes, were estimated for the United States and the EU. As indicated earlier, a separate demand equation for durum wheat is justified because there is little substitutability between durum and any other type of wheat. The durum demand system for the United States includes durum from domestic production and imported Canadian durum. The other demand system for the United States includes domestic spring and other wheat and also imported Canadian western red spring wheat. Even though the United States imports some durum from the EU in the form of pasta, EU durum was not included in the durum demand system because the quantities are negligible.

Similarly, the EU durum demand system in- cludes domestically produced durum, and durum imported from Canada and the United States. The other demand system for the EU includes domestically grown common wheat, spring wheat imported from the United States and Canada, and other types of wheat imported from the United States.

Data on prices and quantities of wheat consumed in the United States including imported wheat were collected from the Wheat Situation and Outlook report. The prices of U.S. other wheat were calculated by taking the weighted average of hard red winter, white, and soft wheat according to their share in consumption. EU domestic wheat prices for durum and common wheat were collected from Agra Europe and Agricultural Situation in the Community. A time series of delivered prices in local currencies for imports was calculated for each wheat class by taking into account FOB prices, the import tariffs and freight rates. For example, Canadian wheat prices in the U.S. were calculated by adding tariffs and freight charges to FOB prices at St. Lawrence. The U.S. tariff on wheat is from the USDA, whereas data on EU import levies are collected from World Wheat Statistics and World Grain Statistics. FOB prices of wheat by classes for Canada and the United States are collected from International Wheat Statistics and International Grain Statistics, published by the International Grains Council.

It has been controversial to use quoted FOB wheat prices for analysis. These prices are not thought to accurately reflect market prices because of hidden subsidies and other special arrangements (Mohanty et al.). In particular, the lack of transparency in the pricing behavior of the Canadian Wheat Board (CWB), which has monopoly power on the marketing of Canadian wheat both domestically and internationally, is often thought to give rise to large asymmetric divergences between the prices actually realized in market transactions and the published price series most commonly used in econometric analysis. But Canadian sales to the U.S. and the EU are not subsidized and the quoted prices are the same as the transaction prices and thus, should be adequate for this analysis.

Annual data for $1971 / 72$ to $1992 / 93$ were used for estimating the demand systems. After estimating the GD/AIDS model, alternate models such as partial and static AIDS models were tested by imposing appropriate coefficient restrictions on the GD/AIDS model. The theoretical demand restrictions of adding-up, homogeneity, and symmetry are also maintained in comparing the different models. As suggested by Anderson and Blundell (1982), economic restrictions such as symmetry 
Table 1. Likelihood Ratio Tests Results for Alternate Dynamic Structures

\begin{tabular}{|c|c|c|c|}
\hline Demand Systems & GD/AIDS $\rightarrow$ GP/AIDS & GP/AIDS $\rightarrow$ S/AIDS & GD/AIDS $\rightarrow$ S/AIDS \\
\hline \multicolumn{4}{|l|}{$\overline{\text { U.S. Durum }}$} \\
\hline$x^{2}$ & 5.6 & 4.49 & 9.49 \\
\hline degrees of freedom & 3 & 1 & 4 \\
\hline critical value & 7.81 & 3.84 & 14.76 \\
\hline \multicolumn{4}{|c|}{ U.S. Spring and Other Wheat } \\
\hline$x^{2}$ & 8.7 & 6.67 & 27.45 \\
\hline degrees of freedom & 8 & 2 & 10 \\
\hline critical value & 15.58 & 5.99 & 18.31 \\
\hline \multicolumn{4}{|l|}{ EU Durum } \\
\hline$x^{2}$ & 6.95 & 6.34 & 21.37 \\
\hline degrees of freedom & 6 & 2 & 8 \\
\hline critical value & 12.59 & 5.99 & 15.51 \\
\hline \multicolumn{4}{|c|}{ EU Spring and other Wheat } \\
\hline$x^{2}$ & 18.8 & 9.65 & 46.24 \\
\hline degrees of freedom & 15 & 3 & 18 \\
\hline critical value & 24.99 & 7.81 & 28.87 \\
\hline
\end{tabular}

GD/AIDS: General dynamic AIDS, GP/AIDS: Generalized partial AIDS model, S/AIDS: Static AIDS.

and homogeneity are imposed only on long-run parameters of the GD/AIDS. The test involved estimating unrestricted and restricted models and computing the likelihood ratio test statistics. The likelihood ratio test statistic is asymptotically distributed as chi-square with degrees of freedom equal to the number of restrictions (Anderson and Blundell 1982).

\section{Empirical Results}

Table 1 reports the test results on the alternate dynamic specifications to represent the demand functions. The likelihood ratio test statistics indicate that the null hypothesis of the generalized partial adjustment model (GP/AIDS) cannot be rejected over GD/AIDS. But both the dynamic specifications (GD/AIDS and GP/AIDS) are preferred to the static AIDS model for all the demand systems. To be consistent with the data, wheat demand is best represented by the dynamic AIDS specifications (GP/AIDS or GD/AIDS) rather than the static AIDS. Although both dynamic specifications are acceptable, the results presented here are for GD/AIDS.

Having established the dynamic structures, the next step is to test the theoretical restrictions of homogeneity and symmetry with the adding-up restrictions imposed. First, homogeneity is tested and, in the next step, both homogeneity and symmetry are tested simultaneously. The results show that both homogeneity and symmetry are accepted for all the demand systems in the long run (table 2).

Finally, each demand system is specified as a GD/AIDS model and is estimated using three-stage least squares with symmetry and homogeneity imposed. After estimating the demand systems, the coefficients of the deleted equation for each demand system are retrieved using the adding up constraint. Tables 3 and 4 present the estimated long-run coefficients, standard errors, $\mathrm{R}$ squares, and Durbin-Watson statistics for U.S. durum, spring, and other wheat demand systems. The $R^{2}$ values indicate relatively good explanatory power for the U.S. equation system. Most of the long-run parameters in the demand systems are significant, suggesting that the specification is appropriate. Similarly, tables 5 and 6 report the estimated and retrieved long-run coefficients along with standard error, R-square, and Durbin-Watson for the EU demand systems.

\section{Table 2. Test Results on Economic Restrictions}

\begin{tabular}{llcc} 
Demand Systems & & Homogeneity & $\begin{array}{c}\text { Homogeneity } \\
\text { and Symmetry }\end{array}$ \\
\hline U.S. Durum & $\chi^{2}$ & 1.5 & 1.5 \\
& df & 1.0 & 1.0 \\
U.S. Spring and & CV & 3.84 & 3.84 \\
Other Wheat & $\chi^{2}$ & 0.50 & 1.6 \\
& & & \\
EU Durum & df & 2.00 & 3.0 \\
& $\mathrm{CV}$ & 5.99 & 7.81 \\
& $\chi^{2}$ & 3.41 & 3.79 \\
EU Spring and & $\mathrm{df}$ & 2.00 & 3.0 \\
Other Wheat & $\mathrm{CV}$ & 5.99 & 7.81 \\
& $\chi^{2}$ & 3.69 & 5.92 \\
& $\mathrm{df}$ & 3.00 & 6.0 \\
& $\mathrm{CV}$ & 7.81 & 12.59 \\
\hline
\end{tabular}

df: degree of freedom, CV: Critical values. 
Table 3. Estimated Coefficients and Standard Errors for the U.S. Durum Demand System

\begin{tabular}{|c|c|c|c|c|c|c|c|}
\hline Share & $\gamma_{i 1}$ & $\gamma_{i 2}$ & $\beta_{i}$ & $\alpha_{i}$ & $\mathbf{R}^{2}$ & DW & $\begin{array}{c}\text { Average Market } \\
\text { Share } \\
(80 / 81-92 / 93)\end{array}$ \\
\hline U.S. Durum & $-0.57(0.25)$ & 0.57 & $-0.28(0.12)$ & $1.89(1.14)$ & 0.71 & 2.05 & 0.85 \\
\hline Canadian Durum & & -0.57 & 0.28 & -0.89 & & & \\
\hline
\end{tabular}

DW: Durbin Watson.

Estimated long-run coefficients are converted to their respective price and expenditure elasticities using the average value from 1988 to 1993 . Uncompensated price and expenditure elasticities for the U.S. and the EU are presented in tables 7 and 8. Table 7 presents the own- and cross-price elasticities, along with expenditure elasticities for durum, spring, and other wheat of different origins consumed in the United States. In table 7, the ownprice elasticity for U.S. durum is -1.164 , whereas the price elasticity for Canadian durum is -5.39 in the U.S. domestic market. This suggests that a $1 \%$ decrease in U.S. durum price will increase the demand of U.S. durum by $1.16 \%$ but the same decrease in the Canadian durum price will trigger a $5.39 \%$ increase in U.S. imports of Canadian durum wheat. Similarly, both the cross-price elasticity and the expenditure elasticity are higher for Canadian durum. This indicates that Canadian wheat is more price responsive than U.S. durum in the U.S. domestic market.

The lower portion of table 7 reports the ownand cross-price elasticities and expenditure elasticities of U.S. spring and other wheat demand systems. As with Canadian durum, Canadian spring wheat is also more price responsive relative to U.S. spring and other wheat in the U.S. domestic market. For example, the own-price elasticity of U.S. spring is -0.85 and other wheat is -0.25 as compared to a price elasticity of -2.76 for Canadian spring wheat. The expenditure elasticity of Canadian spring wheat is also higher than the expenditure elasticities of U.S. spring and other wheat. The higher price response of Canadian wheat in the U.S. market may be due to the fact that the share of imported Canadian wheat in U.S. consumption is very small and Canadian durum and spring wheats sell at a premium because of quality differences between the two countries (Wilson, 1989; Larue; Kraft, Furton and Truchniewic).

Table 8 reports own- and cross-price elasticities along with expenditure elasticities for EU durum, U.S. durum, and Canadian durum in the EU domestic market. Unlike the durum elasticity in the U.S. market, price elasticities of both domestic and imported wheat are very comparable. U.S. durum seems to be slightly more price responsive than Canadian and EU durum in the EU domestic market. Other interesting results are the negative crossprice elasticities between U.S. and Canadian durum wheat and also the negative expenditure elasticities for these two wheats. It is also somewhat puzzling to find negative expenditure elasticities for U.S. and Canadian durum in the EU market. Based on our results, it seems to indicate that EU pasta makers consider EU durum to be superior to either U.S. or Canadian durum.

The lower portion of table 8 reports price and expenditure elasticities for $\mathrm{EU}$ common wheat, $\mathrm{Ca}-$ nadian spring, U.S. spring, and U.S. other wheat in the EU domestic market. EU common wheat and U.S. other wheat, which includes hard red winter, soft red and white wheat, are more price responsive than both U.S. and Canadian spring wheat. The low price responsiveness of spring wheat compared with other classes of wheat may be due to the quality differential between these two wheat groups. Spring wheat is preferred for baking purposes because of its higher protein content and sells at a premium.

Like durum wheat, negative cross-price elasticities (a complementary relationship) exist between spring and other wheat (both U.S. and EU) but the cross-price elasticities are positive between U.S.

Table 4. U.S. Spring and Other Wheat Demand System

\begin{tabular}{|c|c|c|c|c|c|c|c|c|}
\hline Share & $\gamma_{i 1}$ & $\gamma_{i 2}$ & $\gamma_{i 3}$ & $\beta_{i}$ & $\alpha_{i}$ & $\mathrm{R}^{2}$ & DW & $\begin{array}{c}\text { Average Market } \\
\text { Share } \\
(80 / 81-92 / 93) \\
\end{array}$ \\
\hline U.S. Spring & $0.15(0.10)$ & $-0.16(0.11)$ & 0.01 & $-0.08(0.03)$ & $0.99(0.26)$ & 0.56 & 1.58 & 0.20 \\
\hline U.S. Other Wheat & & $0.23(0.13)$ & -0.003 & $0.07(0.03)$ & $0.13(0.30)$ & 0.47 & 1.96 & 0.79 \\
\hline Canadian Spring & & & -0.01 & -0.01 & -0.12 & & & 0.01 \\
\hline
\end{tabular}


Table 5. Estimated Coefficients and Standard Errors for the EU Durum Demand System

\begin{tabular}{|c|c|c|c|c|c|c|c|c|}
\hline Share & $\gamma_{\mathrm{i} 1}$ & $\gamma_{i 2}$ & $\gamma_{\mathrm{i} 3}$ & $\beta_{\mathbf{i}}$ & $\alpha_{i}$ & $\mathrm{R}^{2}$ & DW & $(80 / 81-92 / 93)$ \\
\hline EU Durum & $-0.30(0.13)$ & $0.15(0.08)$ & 0.15 & $0.47(0.14)$ & $-3.27(1.18)$ & 0.76 & 1.76 & 0.85 \\
\hline U.S. Durum & & $-0.30(0.13)$ & 0.23 & $-0.18(0.08)$ & $1.63(0.64)$ & 0.56 & 1.82 & 0.06 \\
\hline Canadian Durum & & & -0.38 & -0.29 & 2.64 & & & 0.09 \\
\hline
\end{tabular}

Table 6. EU Spring and Other Wheat Demand System

\begin{tabular}{|c|c|c|c|c|c|c|c|c|c|}
\hline & $\gamma_{i 1}$ & $\gamma_{i 2}$ & $\gamma_{i 3}$ & $\gamma_{i 4}$ & $\beta_{i}$ & $\alpha_{i}$ & $\mathrm{R}^{2}$ & DW & $\begin{array}{c}\text { Average } \\
\text { Market } \\
\text { Share } \\
(80 / 81-92 / 93)\end{array}$ \\
\hline $\begin{array}{l}\text { EU Common } \\
\text { Wheat }\end{array}$ & $-0.01(0.04)$ & $-0.03(0.01)$ & $-0.02(0.01)$ & 0.06 & $0.11(0.02)$ & $-0.25(0.23)$ & 0.78 & 1.52 & 0.90 \\
\hline $\begin{array}{c}\text { Canadian } \\
\text { Spring }\end{array}$ & & $0.026(0.01)$ & $0.01(0.003)$ & -0.00 & $-0.05(0.01)$ & $0.55(0.13)$ & 0.65 & 1.53 & 0.04 \\
\hline U.S. Spring & & & $0.03(0.01)$ & -0.02 & $-0.03(0.01)$ & $0.36(0.09)$ & 0.84 & 1.85 & 0.04 \\
\hline $\begin{array}{l}\text { U.S. Other } \\
\text { Wheat }\end{array}$ & & & & -0.04 & -0.03 & 0.35 & & & 0.02 \\
\hline
\end{tabular}

Table 7. Estimated Uncompensated Elasticities for the U.S. Domestic Market

\begin{tabular}{|c|c|c|c|c|}
\hline \multirow{2}{*}{$\frac{\text { Type/Source }}{\text { Durum }}$} & \multicolumn{3}{|c|}{ Demand Elasticities with respect to the price of } & \multirow[t]{2}{*}{$\begin{array}{l}\text { Expenditure } \\
\text { Elasticities }\end{array}$} \\
\hline & & & & \\
\hline & U.S. durum & Canadian durum & & \\
\hline U.S. & -1.16 & 0.52 & & 0.65 \\
\hline Canadian & 1.39 & -5.39 & & 3.99 \\
\hline \multicolumn{5}{|c|}{ Spring and Other Wheat } \\
\hline & U.S. Spring & U.S. Other Wheat & Canadian Spring & \\
\hline U.S. Spring & -0.85 & -0.23 & -0.53 & 1.08 \\
\hline U.S. Other Wheat & 0.46 & -0.25 & 0.06 & 0.65 \\
\hline Canadian Spring & -2.40 & 1.73 & -2.76 & 3.43 \\
\hline
\end{tabular}

Table 8. Estimated Uncompensated Elasticities for the EU Domestic Market

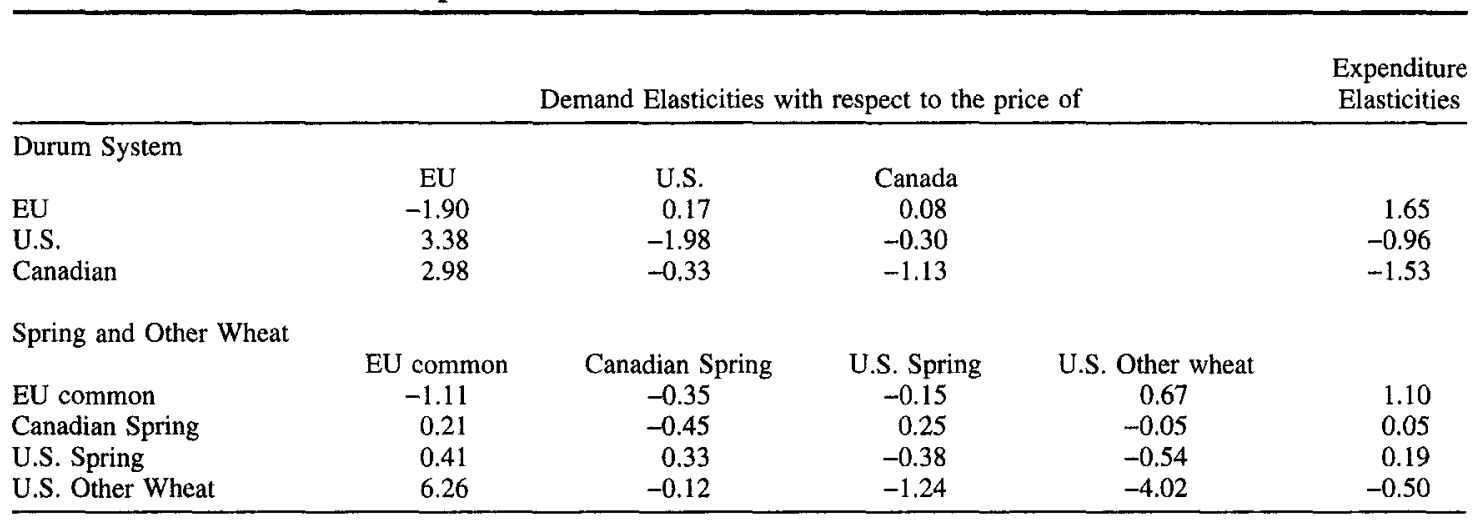


and Canadian spring wheat and also between EU common wheat and U.S. other wheat. Positive cross-price elasticities between wheat of similar quality, i.e., U.S. spring and Canadian spring or U.S. other wheat groups and EU common wheat, are expected because wheats of similar quality substitute for each other. On the other hand, the results suggest negative price elasticities of U.S. other wheat and EU common wheat with respect to the price of U.S. or Canadian spring in the EU market. The complementary relationships between lower quality (U.S. other wheat and EU common wheat) and higher quality (U.S. hard red spring and $\mathrm{Ca}$ nadian western red spring) wheat may be explained by the fact that millers in the EU blend cheaper wheat, such as EU common wheat and U.S. other wheat, with wheat having higher protein content (spring wheat) to obtain the preferred characteristics. Positive cross price elasticities are found for U.S. and Canadian spring wheat with respect to the price of either U.S. other wheat or EU common wheat.

In addition to providing more reliable elasticity estimates, these results are of interest for policy analysis because they show that a particular policy can give rise to effects that are not immediately obvious. For example, larger own- and cross-price elasticities for Canadian durum and spring wheat in the U.S. market suggest that any policy that is designed to lower Canadian prices or to raise U.S. prices would result in extensive substitution of Canadian wheat in the U.S. market. Similarly, higher cross price elasticities for the U.S. and Canadian durum with EU durum wheat in the EU market suggest that a small price reduction for EU durum would result in significant substitution of imported U.S. and Canadian durum for EU durum. Smaller price elasticities for U.S. and Canadian spring wheat in the EU market may be explained by the fact that the EU extracts the gluten (75\% protein) from its soft wheat and blends that with its low protein wheat flour. This activity has reduced the amount of imported U.S. and Canadian wheat that is blended with EU wheat.

Price and expenditure elasticities estimated in this study are not directly comparable with those from other studies because of the difference in assumptions and methods. For example, Alston, Grey, and Sumner reported demand elasticities of Canadian durum and U.S. durum in the U.S. domestic market to be -7.25 and -3.77 , respectively, as compared to our estimates of -5.39 and -1.16 . Similarly, the price elasticity of Canadian hard spring wheat in the U.S. domestic market is estimated to be -2.76 as compared to -9.65 by Alston et al. They did not estimate the elasticities econo- metrically, but rather used an Armington formula to calculate price elasticities by wheat classes from assumed elasticities of substitution between classes and the overall price elasticity of wheat borrowed from other studies.

\section{Conclusion}

Most past studies have estimated demand assuming homogeneity of wheat. In recent years, some studies have stressed the importance of allowing for product differentiation by origin but, except Wilson, others have implicitly assumed perfect substitutability across classes exported from a particular country. As indicated by Wilson (1994), the assumption of either homogeneity or differentiation only by origin is clearly inappropriate because the characteristics of each class of wheat are distinct. This is particularly true for countries like the U.S. and the EU, where multiple classes of domestic and imported wheats are consumed.

This study estimates demand elasticities for wheat differentiated both by origin and end uses for the United States and the EU using a general dynamic AIDS specification. Demand functions were specified from the test results of alternate dynamic structures, which suggests that the dynamic specification is preferred over the static AIDS specification for all the demand systems.

The estimated price elasticities for the U.S. domestic market indicate that imported Canadian durum and spring wheat are highly price responsive compared with the domestic wheat classes in the U.S. market. If this is true, Canadian farm programs (input subsidies) that reduce prices of $\mathrm{Ca}$ nadian wheat in the U.S. market or U.S. programs (Export Enhancement Program) that raise U.S. wheat prices could be expected to give rise to substantial substitution of Canadian for U.S. wheat. Even the expenditure elasticities of Canadian wheat are higher than their respective counterparts for U.S. wheat in U.S. domestic markets.

In contrast to the United States, where price responsiveness depends on national origin (imported wheats are more price responsive than domestically produced wheat), in the EU, price responsiveness varies according to the quality of wheat rather than by national origin. For example, variations in the prices of EU common wheat and U.S. hard red winter and soft wheat trigger greater response than changes in U.S. or Canadian spring wheat prices. The lower response of spring wheat to price variations is explained by its higher quality. It is also found that in the EU, substitution possibilities exist between higher quality wheat such as U.S. spring 
and Canadian spring and also between lower quality wheat such as U.S. other wheat and EU common wheat. In contrast, complementary relationships exist between spring and other wheat groups. This complementary relationship between the lower and higher quality wheat in the EU is not surprising because EU millers blend cheaper wheat such as EU common wheat and U.S. other wheat with high protein (spring) to obtain the preferred characteristics.

A full explanation of the relationships between U.S., Canadian and EU wheat markets requires more than accurate elasticities. There are factors other than wheat prices that influence these markets which would have to be taken into account in a full policy assessment. For example, there may be effects stemming from changes on other markets, such as the market for feed grains, or policies affecting wheat quality or land use. Nevertheless, accurate measures of the extent to which wheat users respond to price variations is an important element in any assessment of the implications of alternative policies or other factors that might influence prices. The estimates presented in this study are consistent with economic theory, take account of product differentiation due to both national origin and the different types of wheat, and can be used in conjunction with other information to provide useful insights into trade disputes and other problems on these important markets.

\section{References}

Agra Europe(London) Ltd. Agra Europe, Various Issues.

Agriculture Canada. 1987. Analysis of Strategic Mixes for Canadian Wheat Exports. Guelph, Ontario: Agriculture Canada.

Alaouze, C.M., A.S. Watson, and N.H. Sturgess. 1978. "Oligopoly Pricing in the World Wheat Market." American Journal of Agricultural Economics 60:173-85.

Alston, J.M., C.A. Carter, R. Green, and D. Pick. 1990. "Whither Armington Trade Models." American Journal of Agricultural Economics 72:455-68.

Alston, J.M., R. Gray, and D.A. Sumner. 1994. "The Wheat War of 1994." Canadian Journal of Agricultural Economics 42:231-51.

Anderson, G.J., and G.R. Blundell. 1982. "Estimation and Hypothesis Testing in Dynamic Singular Equation System." Econometrica 50:1559-71.

—. 1983. "Testing Restrictions in a Flexible Dynamic Demand System: An Application to Consumers' Expenditure in Canada." Review of Economic Studies 50:397-410.

Armington, P.S. 1969. "A Theory of Demand for Products Distinguished by Place of Production." IMF Staff Paper 16: 159-78.

Chai, J. 1972. "The U.S. Food Demand for Wheat by Classes."
Staff Pap. No. P72-14, Department of Agricultural and Applied Economics, University of Minnesota.

Chang, J. 1981. "Analysis of Import Demand for Hard Red Spring and Hard Red Winter Wheat in the International Market.: Unpublished M.S. Thesis, North Dakota State University.

Deaton, A., and J. Muellbauer. 1980. "An Almost Ideal Demand System." American Economic Review 70:312-26.

European Commission. The Agricultural Situation in the European Union. Various Issues.

Gallagher, P., M. Lancaster, M. Bredahl, and T.J. Ryan. 1986. "The U.S. Wheat Economy in an International Setting: An Econometric Investigation." ESS/USDA Technical Bulletin No. 1644, U.S. Department of Agriculture, Washington DC.

Grennes, T., P.R. Johnson, and M. Thursby. 1977. The Economics of World Grain Trade. New York: Praeger Publishers.

Harwood, L.J., and K.W. Bailey. 1990. "The World Wheat Market-Government Intervention and Multilateral Policy Reforms." Staff Report AGEX 9007. Commodity Economics Division, Economic Research Services, USDA.

Hendry, D.F., A.R. Pagan, and J.D. Sargan. "Dynamic Specification." Chapter 18 in Handbook of Econometrics, Vol II (Z. Griliches and M. Intriligator eds). North Holland.

Hennings, C.J., and L.J. Martin. 1989. "An Economic Evaluation of Expanded Canadian 3-M Wheat Exports." Canadian Journal of Agricultural Economics 37:445-65.

International Wheat Council. World Wheat Statistics. Selected Issues.

International Wheat Council. 1991-1995. World Grain Statistics.

Kesavan, T., Z.A. Hassan, H.H. Hensen, and S.R. Johnson. 1993. "Dynamic and Long-Run Structure in U.S. Meat Demand." Canadian Journal of Agricultural Economics 41:139-53.

Kmenta, J. 1986. Element of Econometrics. Macmillan Publishing Company. New York. pp. 485-95.

Konandreas, P., P. Bushnell, and R. Green. 1978. "Estimation of Export Demand Functions for U.S. Wheat." Western Journal of Agricultural Economics 3:39-49.

Kraft, D.F., W.H. Furton, and E.W. Trychniewicz. 1996. "Performance Evaluation of the Canadian Wheat Board." Winnipeg: Canadian Wheat Board (January).

Larue, B. 1991. "Is Wheat a Homogeneous Product?" Canadian Journal of Agricultural Economics 39:103-117.

Leuck, D. 1990. "The Effects of the Common Agricultural Policy on the European Community Wheat-Industry and Grain Trade." Staff Report AGES 9023. Washington, D.C.: ERS/USDA.

McCalla, A.F. 1966. "A Duopoly Model of World Wheat Pricing." American Journal of Agricultural Economics 48: 711-27.

Mohanty, S., E.W.F. Peterson, and N.C. Kruse. 1995. "Price Asymmetry in the International Wheat Market." Canadian Journal of Agricultural Economics 43:355-66.

Organization for Economic Cooperation and Development. 1987. (OECD). National Policies and Agricultural Trade Paris.

Pick, D., A. Webb, E. Dusch, and K. Gudmunds. "Quantitative Assessment of U.S. Wheat Performance or Services and 
Quality Characteristics." Canadian Journal of Agricultural Economics.

Pollak, R.A., and T.J. Wales. 1969. "The Estimation of the Linear Expenditure System." Econometrica 27:611-28.

Sumner, D.A., J.M. Alston, and R. Gray. 1994. "A Quantitative Analysis of the Effects of Wheat Imports on the U.S. Market for Wheat Including the Impact on Deficiency Payments." Report Prepared for the Canadian Wheat Board.

United States Department of Agriculture. 1994. Response to Commission Questions Directed to the USDA. Presented before the International Trade Commission, Investigation No. 22-54 (Wheat, Wheat Flour, and Semolina).

United States Department of Agriculture. Wheat Situation and Outlook Report, Various Issues.

Wang, Y. 1962. "The Demand and Price Structure for Various
Classes of Wheat." Unpublished Ph.D. Dissertation, The Ohio State University.

Wickens, M.R., and T.S. Breusch. 1988. "Dynamic Specification, the Long Run, and the Estimation of Transformed Regression Models." Economic Journals 98:189-205.

Wilson, W.W. 1989. "Differentiation in Export Wheat Markets." Western Journal of Agricultural Economics 14:6777.

Wilson, W.W. 1994. "Demand for Wheat Classes by Pacific Rim Countries." Journal of Agricultural and Resource Economics 19:197-209.

Wilson, W.W., W.W. Koo, and C.A. Carter. 1990. "Importer Loyalty in the International Wheat Market." Journal of Agricultural Economics 41(1):94-102. 